\title{
Vitamin D: an effect on fertility and in vitro fertilization
}

\author{
Jonathas Borges Soares ${ }^{1}$, Ricardo Teodoro Beck², Theodoro Busso Beck Neto ${ }^{3 *}$, \\ Mauren Beatriz Frazon Carbonar ${ }^{3}$, Luciane Moreira ${ }^{3}$, Cristina Terumy Okamoto ${ }^{3}$ \\ 1Projeto ALFA Reprodução Humana Assistida, São Paulo, SP, Brazil \\ ${ }^{2}$ Hospital Maternidade Curitiba, Clínica de Reprodução Humana Dr. Ricardo Beck, Curitiba, PR, Brazil \\ ${ }^{3}$ Universidade Positivo, Curitiba, PR, Brazil
}

\section{Abstract}

Objectives: This study aimed on analyzing vitamin D serum levels and its impact on oocyte quality in patients undergoing in vitro fertilization (IVF) procedures at a human reproduction laboratory located in Curitiba, Brazil. Methods: This article is an observational cross-sectional study of retrospective data collected from the medical history of patients that have undergone IVF treatment between January 2015 and December 2015 in a specialized clinic (Clínica de Reprodução Dr. Ricardo Beck da Maternidade Curitiba) located in Curitiba, Brazil. Different vitamin D levels where compared with a variety of oocyte qualities and in vitro cleavage percentage. Results: We identified a prevalence of deficient $(\leq 20 \mathrm{ng} / \mathrm{mL})$ and insufficient $(21-29 \mathrm{ng} / \mathrm{mL})$ vitamin D levels among the patients in this study. No evidence was found that could confirm an effect of vitamin D on oocyte quality or in vitro cleavage percentage. Conclusion: Age has been shown to be an important factor in altering the number of oocytes available after pharmacological induction and oocytes with adequate quality for implantation at the end of the in vitro cycle. Due to the importance of the subject, further studies are essential for a better understanding of the effect of vitamin D on human fertility and IVF procedures.

Keywords: vitamin D; fertility; in vitro fertilization; IVF.

\section{Introduction}

Vitamin $\mathrm{D}$ is essential for a variety of bodily functions, and its insufficiency may be related to the physiopathogenesis of many known diseases. ${ }^{1}$ Vitamin D deficiency is frequent in most countries and is considered a health issue in the whole world..$^{1-3}$

The American Society of Endocrinology suggests the following reference range of 25-hydroxyvitamin $D$ [25(OH)D], the circulatory form of vitamin D: deficiency $\leq 20 \mathrm{ng} / \mathrm{mL}$, insufficiency $21-29 \mathrm{ng} / \mathrm{m}$, and land sufficiency $\geq 30 \mathrm{ng} / \mathrm{mL} .{ }^{4}$ Although the ideal serum levels of $25(\mathrm{OH}) \mathrm{D}$ are controversial, the most authors agree that levels of $<30-32 \mathrm{ng} / \mathrm{ml}$ describe a deficit in vitamin D. 5,6

Among many dysfunctions of the human's body that low vitamin D can cause, it is relevant to bring attention to its interference in sexual reproduction. The relationship between vitamin D shortage and human reproduction was initially shown in experiments using lab rats.7,8 An experimental study conducted by Halloran and collaborators shows that female rats that were fed with low vitamin $D$ diets had a $75 \%$ reduction in fertility and $30 \%$ reduction in pregnancy rates. $^{9}$ Other studies analyzed the effect of vitamin D deficiency on in vitro fertilization (IVF) procedures. The results demonstrate an increase in the rate of implantation and IVF success in patients with adequate 25(OH)D levels when compared to patients with inadequate levels of $25(\mathrm{OH}) \mathrm{D} .8,10,11$

Financial support: None.

Conflicts of interest: The authors declare no conflicts of interest.

Submitted: September 12, 2017.

Accepted: November 21, 2017.

Study carried out at Clínica de Reprodução Humana Dr. Ricardo Beck at the hospital Maternidade Curitiba (CRHC), Curitiba, PR, Brazil.

Copyright Soares et al. This is an Open Access article distributed under the terms of the Creative Commons Attribution License, which permits unrestricted use, distribution, and reproduction in any medium, provided the original work is properly cited. 


\section{Objectives}

\section{Primary objective}

To analyze 25(OH)D serum levels in patients submitted to IVF treatment at a human reproduction laboratory located in Curitiba, Brazil.

\section{Secondary objective}

To evaluate the oocyte quality and in vitro cleavage success and compare these results to vitamin D levels in each patient group.

\section{Methodology}

This article is an observational cross-sectional study of retrospective data collected from the medical history of patients that have undergone IVF treatment between January 2015 and December 2015 in a specialized clinic (Clínica de Reprodução Dr. Ricardo Beck da Maternidade Curitiba) located in Curitiba, Brazil.

The inclusion criteria were as follows: all medical records of patients presented a complete history of the IVF procedure, including a complete record on the evolution of the eggs in the laboratory and vitamin D dosing before the beginning of the procedure. Exclusion criteria were as follows: patients who did not present 25(OH)D serum level results; incomplete charts that did not present a report containing all the characteristics of the fertilization and embryo divisions accompanied by the evolution during the IVF procedure; the cause of infertility was due to the male factor or when the semen used was not of appropriate quality for successful fertilization. After applying all exclusion factors, 36 medical records where included in this study.

Data collection was conducted during a four-month period (May 2016 - August 2016). Data were organized using Microsoft Exce ${ }^{\circledR}$ software and analyzed using Kruskal-Wallis test followed by Dunn's test, which are normally used for the comparison of three or more groups.

\section{Results}

In 39 medical records that where analyzed, patients' age ranged from 28 to 45 years with an average of 36 years. These data are included in Table 1.

When analyzing the dosage of vitamin D regardless of age, nine (25\%) patients had poor vitamin D levels, $18(50 \%)$ patients had insufficient vitamin D levels, and nine (25\%) patients had sufficient vitamin D levels.

Considering the total number of patients, an average value of vitamin D serum levels obtained was $27.7 \mathrm{ng} / \mathrm{mL}$ (standard deviation $9.8 \mathrm{ng} / \mathrm{mL}$; minimum $12 \mathrm{ng} / \mathrm{mL}$; maximum $65 \mathrm{ng} / \mathrm{mL}$ ). These data can be found in table 2 .

To better understand and analyze the results, we divided the patients into three main groups according to their age. In group 1, 17 (47.2\%) medical records of patients who were 28-34-years-old were included. In group 2, nine (25\%) medical records of patients aged between 35 and 39 years were selected. In group 3, 10 (27.8\%) patients over the age of 40 years were included. Table 3 shows the comparison of the three main groups according to the patient's age, group, and nine subgroups based on vitamin D levels (Table 3).

Of the 17 patients in group 1, five presented with vitamin D deficiency (VDD), seven presented with vitamin $D$ insufficiency (VDI), and five presented with sufficient vitamin D (VDS) levels. Of the nine patients in group 2, two presented with VDD, five presented with VDI, and two presented with VDS. In group 3, we had a total of 10 patients: two with VDD, six with VDI, and two with VDS (Table 3).

In Tables 4 and 5, the variables used in the cross-over between the three groups are shown, including arithmetic mean, standard deviation, median, minimum, and maximum. These data were collected to analyze the quality of the material in vitro and subsequently to correlate them with the age of the patients and their vitamin D dosage.

Table 1. Groups by age

\begin{tabular}{ccc}
\hline Age range & No. of patients & Total percentage \% \\
\hline Group 1 - 28 to 34 years & 17 & 47.2 \\
Group 2 - $\mathbf{3 5}$ to $\mathbf{3 9}$ years & 9 & 25.0 \\
Group 3 - $\mathbf{4 0}$ to $\mathbf{4 5}$ years & 10 & 27.8 \\
\hline
\end{tabular}


Table 2. Serum levels of Vitamin D

\begin{tabular}{|cccccc|}
\hline Variable & AM & SD & Med & Min & Max \\
Vitamin D & $27.7 \mathrm{ng} / \mathrm{mL}$ & $9.8 \mathrm{ng} / \mathrm{mL}$ & $26.1 \mathrm{ng} / \mathrm{mL}$ & $12 \mathrm{ng} / \mathrm{mL}$ & $65 \mathrm{ng} / \mathrm{mL}$
\end{tabular}

AM: arithmetic mean; SD: standard deviation; Med: median; Min: minimum; Max: maximum.

Table 3. Division into groups by age group $x$ vitamin $D$ level

\begin{tabular}{|ccccc}
\hline Groups & $\begin{array}{c}\text { Total } \\
\text { no. of } \\
\text { patients }\end{array}$ & $\begin{array}{c}\text { No. of patients with } \\
\text { deficient vitamin D } \\
\text { (Subgroup 1) }\end{array}$ & $\begin{array}{c}\text { No. of patients with } \\
\text { insufficient vitamin D } \\
\text { (Subgroup 2) }\end{array}$ & $\begin{array}{c}\text { No. of patients with } \\
\text { sufficient vitamin D } \\
\text { (Subgroup 3) }\end{array}$ \\
Group 1 - Patients (28-34-years-old) & 17 & 5 & 7 & 5 \\
Group 2 - Patients (35-39-years-old) & 9 & 2 & 5 & 2 \\
Group 3 - Patients (> 40-years-old) & 10 & 2 & 6 & 2
\end{tabular}

Table 4. Variables analyzed in this study

\begin{tabular}{llllc}
\multicolumn{1}{c}{ Variables } & AM & SD & Med & Min \\
Aspirated oocytes & 6.6 & 3.3 & 6 & 2 \\
Atretic oocytes (day 1 in vitro) & 0.2 & 0.5 & 0 & 0 \\
Degenerated oocytes (day 2 in vitro) & 0.4 & 0.9 & 0 & 0 \\
Oocytes that failed to divide (day 3 in vitro) & 0.2 & 0.5 & 0 & 0 \\
Rate of successfully divided oocytes & 5.8 & 3.1 & 5.5 & 0 \\
\hline
\end{tabular}

AM: arithmetic mean; SD: standard deviation; Med: median; Min: minimum; Max: maximum.

Table 5. Analysis of variables between age groups (values presented as mean \pm standard deviation)

\begin{tabular}{|c|c|c|c|c|}
\hline Variables & $\begin{array}{l}\text { 28-34-years-old } \\
\text { (group 1) }\end{array}$ & $\begin{array}{l}\text { 35-39-years-old } \\
\text { (group 2) }\end{array}$ & $\begin{array}{c}>40 \text {-years-old } \\
\text { (group 3) }\end{array}$ & $\mathbf{p}$ \\
\hline Aspirated oocytes & $7.9 \pm 3.0$ & $7.1 \pm 3.5$ & $4.0 \pm 2.2$ & 0.008 \\
\hline Atretic oocytes (day 1 in vitro) & $0.3 \pm 0.6$ & $0.2 \pm 0.7$ & $0.0 \pm 0.0$ & 0.255 \\
\hline Degenerated oocytes (day 2 in vitro) & $0.5 \pm 1.0$ & $0.8 \pm 1.1$ & $0.0 \pm 0.0$ & 0.072 \\
\hline Oocytes that failed to divide (day 3 in vitro) & $0.4 \pm 0.5$ & $0.0 \pm 0.0$ & $0.2 \pm 0.6$ & 0.091 \\
\hline Rate of successfully divided oocytes & $6.8 \pm 3.0$ & $6.1 \pm 3.0$ & $3.8 \pm 2.2$ & 0.031 \\
\hline
\end{tabular}

Among all patient groups, the mean number of aspirated oocytes was 6.6. The number of atretic oocytes, those that did not evolve well, is counted on the first day in vitro, soon after insemination. During the analysis of atretic oocyte data, an average of 0.2 was found. Between the first and second day in vitro it is possible to quantify the number of oocytes that degenerated during the natural division process. We obtained an average of 0.4 degenerates. From the second to the third day, the count of oocytes that failed in the division is performed, with an average of 0.2 in our analysis. The last data collected in this study was termed the "success rate of the in vitro division", which means the number of oocytes that completed their division successfully during the in vitro period and were presented as a viable material to be transferred to the maternal uterus. The mean of successful division rate was 5.8 (standard deviation 3.1; median, 5.5; minimum 0; maximum 12) oocytes with transfer quality (Table 4). 
After crossing the data of the first five variables within the three age groups, we observed the quantification of aspirated oocytes. In group 1 we obtained a mean of 7.9 (standard deviation, 3) oocytes. In group 2, a mean of 7.1 (standard deviation, 3.5) oocytes was obtained. In group 3, the mean was 4 oocytes (standard deviation, 2). Among the three groups, there was a statistically significant difference $(p=0.008)$, group 1 being the one with younger patients aged between 28 and 34 years, which showed a higher number of oocytes aspirated after induction. The number of oocytes aspirated in group 1 was considerably higher than in group 3 (49.3\% higher). These results demonstrate that the response to induction medication, which is production of oocytes by the ovary, was higher in younger patients (Table 5).

Next, the data were compared between the first five variables within each age group and among the subgroups (Table 5).

When analyzing the number of atretic oocytes on the second day in vitro, a mean of 0.3 (standard deviation, 1) oocytes was reported in group 1, 0.8 (standard deviation, 1.1) oocytes in group 2, and 0 (standard deviation, 0) oocytes in group 3. However, no statistically significant difference was present between the groups. Non-divided oocytes on the third day in vitro had a mean of 0.4 (standard deviation, 0.5) oocytes in group 1, 0 (standard deviation, 0) oocytes in group 2, and 0.2 (standard deviation, 0.6 ) oocytes in group 3. However, no statistically significant difference was present between the groups. The division rate quantified an average of 6.8 (standard deviation, 3) viable oocytes for transfer in group 1, 6.1 (standard deviation, 3) viable oocytes in group 2, and 3.8 (standard deviation, 2.2) viable oocytes in group 3. The results for this variable reached statistical significance $(p=0.031)$. These Results can be found in table 5 .

The results of analysis of vitamin D levels based on the five previously presented variables can be found in Table 9.

When evaluating the amount of atretic oocytes on the first day in vitro, in the VDD group ( $\leq 20 \mathrm{ng} / \mathrm{mL})$, the mean was 0 (standard deviation, 0) oocytes. In the VDI group (21-29 ng/mL), the mean was 0.1 (standard deviation, 0.2) oocytes. In the VDS group ( $\geq 30 \mathrm{ng} / \mathrm{mL}$ ), the mean was 0.7 (standard deviation, 0.9 ) oocytes. The results presented statistical significance $(p=0.008)$. The data point to a higher number of atretic oocytes in patients with adequate levels of vitamin D (Table 9).

Table 6. Analysis of the variables in group 1

\begin{tabular}{cccccc}
\hline Group 1 & Aspirated oocytes & Atretic oocytes & $\begin{array}{c}\text { Degenerated } \\
\text { oocytes }\end{array}$ & $\begin{array}{c}\text { Oocytes that } \\
\text { failed to divide }\end{array}$ & $\begin{array}{c}\text { Rate of } \\
\text { successfully } \\
\text { divided oocytes }\end{array}$ \\
AM & 7.9 & 0.3 & 0.5 & 0.4 & 6.8 \\
SD & 3.0 & 0.6 & 1.0 & 0.5 & 3.0 \\
\hline
\end{tabular}

AM: arithmetic mean; SD: standard deviation.

Table 7. Analysis of the variables in group 2

\begin{tabular}{|c|c|c|c|c|c|}
\hline Group 2 & Aspirated oocytes & Atretic oocytes & $\begin{array}{l}\text { Degenerated } \\
\text { oocytes }\end{array}$ & $\begin{array}{l}\text { Oocytes that } \\
\text { failed to divide }\end{array}$ & $\begin{array}{c}\text { Rate of } \\
\text { successfully } \\
\text { divided oocytes }\end{array}$ \\
\hline AM & 7.1 & 0.2 & 0.8 & 0.0 & 6.1 \\
\hline SD & 3.5 & 0.7 & 1.1 & 0.0 & 3.0 \\
\hline
\end{tabular}

AM: arithmetic mean; SD: standard deviation.

Table 8. Analysis of the variables in group 3

\begin{tabular}{|c|c|c|c|c|c|}
\hline Grupo 3 & Aspirated oocytes & Atretic oocytes & $\begin{array}{l}\text { Degenerated } \\
\text { oocytes }\end{array}$ & $\begin{array}{l}\text { Oocytes that } \\
\text { failed to divide }\end{array}$ & $\begin{array}{c}\text { Rate of } \\
\text { successfully } \\
\text { divided oocytes }\end{array}$ \\
\hline AM & 4.0 & 0.0 & 0.0 & 0.2 & 3.8 \\
\hline SD & 2.2 & 0.0 & 0.0 & 0.6 & 2.2 \\
\hline
\end{tabular}

AM: arithmetic mean; SD: standard deviation. 
Table 9. Groups based on vitamin D levels (values presented as mean \pm standard deviation)

\begin{tabular}{|c|c|c|c|c|}
\hline Aspirated oocytes & $6.6 \pm 3.4$ & $6.3 \pm 3.1$ & $7.3 \pm 3.9$ & 0.756 \\
\hline Degenerated oocytes (day 2 in vitro) & $0.6 \pm 1.3$ & $0.3 \pm 0.8$ & $0.4 \pm 0.7$ & 0.829 \\
\hline Oocytes that failed to divide (day 3 in vitro) & $0.2 \pm 0.4$ & $0.1 \pm 0.3$ & $0.4 \pm 0.7$ & 0.345 \\
\hline
\end{tabular}

*p with statistical significance.

\section{Discussion}

Women fertility declines from the age of 30 years, and there is a 50\% reduction in gestation from the age of 40 years. Moreover, during reproductive life, oocyte numbers decrease rapidly as oocyte quality changes. ${ }^{11}$ The European Society of Human Reproduction and Embryology (ESHRE) recognizes age as an accurate marker for assisted reproduction gestation rate. ${ }^{12}$ The mean age of the patients in this study was 36 years, with the majority being 30 years or older. We analyzed the results from three main age groups, since it is a fundamental criterion in human reproduction. We then compared each group based on the levels of vitamin $D$.

The American Society of Endocrinology suggests the following 25(OH)D reference values to quantify and classify body vitamin $D$ levels: deficiency $\leq 20 \mathrm{ng} / \mathrm{mL}$, insufficiency $21-29 \mathrm{ng} / \mathrm{mL}$, and ideal/sufficient $\geq 30 \mathrm{ng} / \mathrm{mL} .{ }^{4}$ Based on this classification we analyzed vitamin D dosage in patients submitted to IVF. In our study, 25\% of patients had VDD, $50 \%$ had VDI, and 25\% had VDS. There was a significant difference between vitamin D dosages in each patient submitted to the IVF procedure.

When separated by age groups, with vitamin $D$ results classified as sufficient, we obtained only five of the 17 patients between the age of 28 and 34 years; two of the nine patients between the age of 35 and 39 years; and two out of 10 aged 40 years or over. Regarding vitamin D results by age group, there was no significant difference in the vitamin $D$ ratio. There was a higher prevalence of insufficient and deficient vitamin $D$ values. We can attribute this high index of vitamin D deficiency and insufficiency to environmental factors, such as low sun exposure and lower incidence of sun rays in the southern hemisphere, since most patients in the study reside in the state of Paraná, a state located in the south of Brazil. However, the Panffoni et al. study described a higher vitamin D value in the group of patients who were younger. ${ }^{13}$

In assisted reproduction procedures, the quality of oocytes is more relevant than the quantity of oocytes when considering the success rates or gestation rates. However, there is no objective and direct method that evaluates oocyte quality; therefore, indirect markers are used. Among these, age as being indicated as one of the most important markers. Age is considered to be a better marker than follicle-stimulating hormone levels for gestation and implantation rate as well as for abortion. These parameters ultimately reflect oocyte quality. ${ }^{11}$ It is known that pregnancy rate increases with the number of embryos transferred, and the implantation rate correlates positively with good morphology and embryonic cleavage stage. ${ }^{14}$

Regarding the number of oocytes aspirated compared to age groups, the older patients obtained fewer aspirated oocytes. This result is consistent with the literature, since we already know that there is a greater efficiency of fertilization processes in younger patients. ${ }^{15}$

In this work, age was a factor influencing the quantity of oocytes with good transfer quality. This result is confirmed by the literature, since several characteristics of oocytes change with age, which confers a lower quality to the germinative material produced by the older patients. ${ }^{15}$

We noticed a subtle difference between the number of oocytes produced in the different vitamin $D$ groups. Although not achieving statistical significance, the results may suggest a greater response to induction in patients with adequate levels of vitamin D. Comparing with another study, the number of oocytes aspirated between patients with adequate and insufficient vitamin D was not significant. Contrary to our results, the mean number of oocytes in the adequate vitamin D group was 7.9, and it was 0.2 higher than that in the insufficient vitamin D group. ${ }^{13}$

The less satisfactory results observed in techniques of assisted reproduction in women over 40 years are due to the reduction in implantation rates, increase in the rates of spontaneous abortions, low response to the process of ovarian stimulation, and poor quality of oocytes collected. ${ }^{16} \mathrm{It}$ is expected that improved understanding of oocyte genetics and the way it contributes to embryo viability may provide new indicators that are capable of directly assessing oocyte quality. ${ }^{11}$ 
Some studies suggest that the levels of serum $25(\mathrm{OH}) \mathrm{D}$ as a marker of vitamin D levels may be a predictor of pregnancy in women undergoing the IVF treatment. However, they claim that the mechanism of action of vitamin D in fertility is unclear. In our study, regarding different vitamin D levels in patient groups, the only result with statistical significance was obtained during the analysis of atretic oocytes on the first day in vitro. Different than expected, patients with sufficient vitamin $D$ had a higher mean number of atretic eggs. Therefore, although there was a good dosage of vitamin $D$ in the patients, this was not a factor that helped in this stage of IVF. In the future, studies should focus on determining this mechanism, including an evaluation of the characteristics of the germ material in the laboratory, implantation process, and uterine adaptation to pregnancy. Studies should also cover how vitamin D supplementation can positively affect the outcomes of the IVF procedure. ${ }^{8}$

In contrast to studies correlating the success of IVF and vitamin D, there is a study that examined 517 patients and showed no relationship between vitamin D levels and higher pregnancy rate in women who went through the IVF treatment. The article also concludes that measuring vitamin $\mathrm{D}$ levels is not able to predict the chances of the egg implantation in the uterus, but that these results may be different for women who are not undergoing assisted reproductive therapy.

An increasing number of studies suggest that vitamin D levels in each individual may negatively impact reproductive functions. ${ }^{8,17,18}$ However, the paucity of prospective interventional studies and studies that define the mechanism by which vitamin D actually affects reproductive physiology emphasizes the need for further studies with clinical trial design. The pathological mechanism that explains the influence of vitamin D deficiency in reproductive stages is not yet clear, but some evidence suggests that it has a multifactor basis, involving hypothalamic-pituitary regulation, ovarian folliculogenesis, and uterine implantation. ${ }^{13}$ Some animal studies demonstrated this relationship, but control case studies are needed to establish the influence of vitamin D on the chances of pregnancy. $9,13,17-20$

In our study, it was not possible to find a relationship between vitamin D and oocyte quality in vitro. However, vitamin D supplementation is inexpensive, easy to administer, and without significant side effects. Since any adjuvant in the treatment can be beneficial and the success in assisted reproduction is extremely sought by the patients, it is valid to consider the replacement of this vitamin within the IVF treatment.

\section{Conclusion}

There was a significant difference between vitamin D dosages in the patients submitted to the IVF procedure, with a high prevalence of deficient and insufficient vitamin $D$. We found no evidence of a significant effect of vitamin $D$ on oocyte quality, success rate of in vitro division, and IVF process as a whole. Age was shown to be an important factor in the number of oocytes produced by the ovaries after induction and in the number of quality eggs implanted at the end of the in vitro cycle. Due to the importance of the topic for health professionals and the impact on the lives of couples suffering from infertility, it is critical to expand studies that will produce a greater understanding of vitamin $D$ effects on women fertility and the IVF procedure.

\section{References}

1. Maeda SS, Borba VZC, Camargo MBR, Silva DMW, Borges JLC, Bandeira F, Castro-Lazaretti M, et al. Recomendações da Sociedade Brasileira de Endocrinologia e Metabologia (SBEM) para o diagnóstico e tratamento da hipovitaminose D. Arq Bras Endocrinol Metab. 2014;58(5):411-33.

2. Unger MD, Cuppari L, Titan SM, Magalhães MC, Sassaki AL, Reis LM, et al. Vitamin D status in a sunny country: where has the sun gone? Clin Nutr. 2010;29(6):784-8. PMid:20637530. http://dx.doi.org/10.1016/j.clnu.2010.06.009.

3. Peters BS, dos Santos LC, Fisberg M, Wood RJ, Martini LA. Prevalence of vitamin D insufficiency in Brazilian adolescents. Ann Nutr Metab. 2009;54(1):15-21. PMid:19194104. http://dx.doi.org/10.1159/000199454.

4. Lichtenstein A, Ferreira-Júnior M, Sales MM, Aguiar FB, Fonseca LAM, Sumita NM, et al. Vitamina D: ações extraósseas e uso racional. Rev Assoc Med Bras. 2013;59(5):495-506. PMid:24094756. http://dx.doi.org/10.1016/j.ramb.2013.05.002.

5. Hollis BW. Assessment of vitamin D status and definition of a normal cir-culating range of 25-hydroxyvitamin D. Curr Opin Endocrinol Diabetes Obes. 2008;15(6):489-94. PMid:18971676. http://dx.doi.org/10.1097/MED.0b013e328317ca6c.

6. Kuchuk NO, Pluijm SMF, van Schoor NM, Looman CWN, Smit JH, Lips P. Relationships of serum 25-hydroxyvitamin D to bone mineral density and serum parathyroid hormone and markers of bone turnover in older adults. J Clin Endocrinol Metab. 2009;94(4):124450. PMid:19158198. http://dx.doi.org/10.1210/jc.2008-1832.

7. Alves M, Bastosa M, Leitão F, Marques G, Ribeiro G, Carrilho F. Vitamina D - importância da avaliação laboratorial. Rev Port Endocrinol Diabetes Metab. 2013;8(1):32-9.

8. Garbedian K, Boggild M, Moody J, Liu KE. Effect of vitamin D status on clinical pregnancy rates following in vitro fertilization. CMAJ. 2013;1(2)

9. Halloran BP, Deluca HF. Effect of vitamin D deficiency on fertility and reproductive capacity in the female rat. J Nutr. 1980;110(8):157380. PMid:7400847. 
10. Dzik A, Donadio NF, Esteves S, Nagy Z, organizadores. Atlas de reprodução assistida. São Paulo: SBRH; 2012.

11. Abreu LG, Santana LF, Navarro PAAS, Reis RM, Ferriani RA, Moura MD. A taxa de gestação em mulheres submetidas a técnicas de reprodução assistida é menor a partir dos 30 anos. Rev Bras Ginecol Obstet. 2006;28(1):32-7. http://dx.doi.org/10.1590/ S0100-72032006000100006.

12. Baird DT, Collins J, Egozcue J, Eyers LH, Gianaroli L, Leridon H, et al. Fertility and ageing. Hum Reprod Update. 2005;11(3):261-76. PMid:15831503. http://dx.doi.org/10.1093/humupd/dmi006.

13. Paffoni A, Ferrari S, Viganò P, Pagliardini L, Papaleo E, Candiani M, et al. Vitamin D deficiency and infertility: insights from in vitro fertilization cycles. J Clin Endocrinol Metab. 2014;99(11):E2372-6. PMid:25121462. http://dx.doi.org/10.1210/jc.2014-1802.

14. Moura MD, Oliveira VA, Sala MM, Ferriani RA, Reis RM. Comparação entre três escores embrionários como fator prognóstico do sucesso em fertilização in vitro. Rev Bras Ginecol Obstet. 2003;25(3):177-83. http://dx.doi.org/10.1590/S0100-72032003000300006.

15. Chuang CC, Chen CD, Chao KH, Chen SU, Ho HN, Yang YS. Age is a better predictor of pregnancy potential than basal folliclestimulating hormone levels in women undergoing in vitro fertilization. Fertil Steril. 2003;79(1):63-8. PMid:12524065. http://dx.doi. org/10.1016/S0015-0282(02)04562-4.

16. Gomes LMO, Canha AS, Dzik A, Novo NF, Juliano Y, Santos SIS, Cavagna M. A idade como fator prognóstico nos ciclos de fertilização in vitro. Rev Bras Ginecol Obstet. 2009; 31(5):230-4 233.

17. Hickie JP, Lavigne DM, Woodward WD. Reduced fecundity of vitamin D deficient rats. Comp Biochem Physiol A Comp Physiol. 1983;74:9235.

18. Kovacs CS, Woodland ML, Fudge NJ, Friel JK. The vitamin D receptor is not required for fetal mineral homeostasis or for the regulation of placental calcium transfer in mice. Am J Physiol Endocrinol Metab. 2005;289(1):E133-44. PMid:15741244. http:// dx.doi.org/10.1152/ajpendo.00354.2004.

19. Luk J, Torrealday S, Neal Perry G, Pal L. Relevance of vitamin D in reproduction. Hum Reprod. 2012;27(10):3015-27. PMid:22824625. http://dx.doi.org/10.1093/humrep/des248.

20. Ozkan S, Jindal SD, Greenseid K, Shu J, Zeitlian G, Hickmon C, et al. Replete vitamin D stores predict reproductive success following in vitro fertilization. Fertil Steril. 2010;94(4):13149. PMid:19589516. http://dx.doi.org/10.1016/j.fertnstert.2009.05.019.

\author{
*Correspondence \\ Theodoro Busso Beck Neto \\ Rua Santa Cecilia, 305, Bairro Vista Alegre \\ CEP 80820-070, Curitiba, PR, Brazil \\ Tel.:+55 (41) 99926-0560 \\ E-mail: beckneto@hotmail.com
}

\title{
Authors information
}

JBS - M.D., specialist in fertility and human reproduction, Projeto ALFA Reprodução Humana Assistida. RTB - M.D., specialist in fertility and human reproduction, Clínica de Reprodução Humana Dr. Ricardo Beck, Maternidade Curitiba. TBBN - M.S., Universidade Positivo, Paraná, Brazil. MBFC - M.S., Universidade Positivo, Paraná, Brazil. LBM - M.D., Universidade Positivo, Paraná, Brazil. CTO - M.D., Universidade Positivo, Paraná, Brazil.

\section{Author contribution}

JBS - Medical Doctor by Faculdade de Medicina da Universidade de São Paulo (FMUSP) and Specialist in fertility and human reproduction and director at Projeto ALFA Reprodução Humana Assistida, São Paulo, Brazil . RTB - Medical Doctor and Master in Surgery by Universidade Evangélica do Paraná and Specialist in fertility and human reproduction and director at Clínica de Reprodução Humana Dr. Ricardo Beck, Maternidade Curitiba. TBBN - Medical student at Universidade Positivo, Paraná, Brazil. MBFC - Medical student at Universidade Positivo, Paraná, Brazil. LBM - Doctor ophthalmologist at Hospital de olhos do Paraná, doctor in ophthalmology by Universidade Federal de São Paulo and Professor at the School of Medicine, Universidade Positivo, Paraná, Brazil. CTO - Professor at the School of Medicine, Universidade Positivo, Paraná, Brazil. 